\title{
UMH 916, UMH 972, UMH 1093, UMH 1127, and UMH 1139: Four Fresh- market Breeding Lines Resistant to Viruses Within the Muchamiel Tomato Type
}

\author{
Santiago García-Martínez, Adrián Grau, Aranzazu Alonso, \\ Fernando Rubio, Pedro Carbonell, and Juan J. Ruiz ${ }^{\mathbf{1}}$ \\ Departamento de Biología Aplicada, Universidad Miguel Hernández, \\ Escuela Politécnica Superior de Orihuela, Carretera de Beniel, km. 3,2, \\ 03312, Orihuela, Spain
}

Additional index words. ToMV, TSWV, $T m-2^{a}$ gene and $S w-5$ gene

Muchamiel is a tomato (Solanum lycopersicum L.) landrace of Marmande type, very popular in southeastern Spain due to its excellent organoleptic fruit quality. Fruits of the Muchamiel cultivars are medium-large in size (150-300 g), multilocular (five or more locules), flattened and strongly ribbed, green shoulder, and red flesh. The melting texture and mild flavor of these fruits makes them highly valued in salads. However, the incidence of several viruses as Tomato mosaic virus (ToMV), Tomato spotted wilt virus (TSWV), and Tomato yellow leaf curl virus (TYLCV) can make the Muchamiel (and other) landraces cultivation nonviable in many areas, especially in open field (Picó et al., 2002). The Miguel Hernández University breeding program for the introgression of virus into Spanish landraces has resulted in the release of the UMH 1200 breeding line, homozygous for $T m-2^{a}, T y-1$, and $S w-5$ genes (García-Martínez et al., 2011). This breeding line allows farmers to obtain an acceptable harvest with intense virus incidence conditions. However, important yield decreases (ranging between $50 \%$ and $75 \%$ ) have been reported for UMH 1200 with low virus incidence conditions (García-Martínez et al., 2011). This result is due to the introgressed genes and/or to the linkage drag, as previously has been reported in processing tomatoes (Tanksley et al., 1998). The introgression of the TYLCV resistance is responsible for most of the yield decrease obtained in fresh tomato (Rubio et al., 2012). For this reason, we have developed breeding lines without TYLCV resistance. UMH 916 and UMH 972 have genetic resistance to ToMV,

Received for publication 26 Feb. 2015. Accepted for publication 9 Apr. 2015.

This work was partially supported by the Spanish MICINN through projects AGL2005-03946, AGL2008-03822 and AGL2011-26957.

${ }^{1}$ To whom reprint requests should be addressed; e-mail juanj.ruiz@umh.es. whereas UMH 1127 and UMH 1139 have genetic resistance to ToMV and TSWV. The four breeding lines showed similar or better marketable yield than the traditional cultivar Muchamiel 18 (M18) and the breeding line UMH 1200.

\section{Origin}

The breeding lines UMH 916, UMH 972, UMH 1127, and UMH 1139 were obtained by crossing a Muchamiel cultivar (accession M18, previously selected for fruit morphological characteristics, uniformity, and high yield) with the commercial cultivar Anastasia $F_{1}$ (Seminis Vegetable Seeds, Saint Louis, MO), used as the donor parent of the
$T m-2^{a}, S w-5$, and $T y-1$ genes (Pérez de Castro et al., 2007), conferring resistance to ToMV, TSWV, and TYLCV, respectively. Ten (for UMH 916 and UMH 972) and six (for UMH 1127 and UMH 1139) generations of modified backcrossing to the Muchamiel cultivar, with marker assisted selection for three virus resistance genes, were performed. Several trials under different infection conditions (mechanical inoculation for ToMV and natural infection for TSWV) were carried out to control the presence of the resistance alleles in the first backcross (BC) generations and the effectiveness of the molecular markers. In addition, a high selection pressure for Muchamiel characteristics (flattened and ribbed shape, green shoulder) and good agronomic behavior (proper fruit set, sufficient uniformity among fruits and yield) were applied during modified backcrossing. Progenies for each backcross generations were screened with molecular markers. All plants simultaneously containing all the introduced resistance genes (usually between five and 10

Table 1. Genotype for each resistance gene (RR: resistant homozygous, ss: susceptible homozygous) for the new four breeding lines. The UMH 1200 breeding line and the accession M18 are included as reference.

\begin{tabular}{lcll}
\hline & \multicolumn{3}{c}{ Genotype } \\
\cline { 2 - 4 } Breeding line/cultivar & $T m-2^{a}$ & $T y-1$ & $S w-5$ \\
\hline UMH 916 & RR & Ss & ss \\
UMH 972 & RR & ss & ss \\
UMH 1127 & RR & ss & RR \\
UMH 1139 & RR & ss & RR \\
UMH 1200 & RR & RR & RR \\
Accession M18 & Ss & ss & ss \\
\hline
\end{tabular}

Table 2. Yield traits, soluble solids content (SSC), and titratable acidity (TA) of the breeding lines UMH 916, UMH 972, UMH 1127, UMH 1139, and UMH 1200 and Muchamiel landrace (accession M18) grown in a mesh-covered net house in the spring-summer crop cycle the last 3 years.

\begin{tabular}{lccclc}
\hline & $\begin{array}{c}\text { Marketable } \\
\text { yield (kg/plant) }\end{array}$ & $\begin{array}{c}\text { Avg fruit } \\
\text { wt }(\mathrm{g})^{\mathrm{z}}\end{array}$ & $\begin{array}{c}\text { Fruit number } \\
\text { per plant }^{\mathrm{z}}\end{array}$ & $\begin{array}{c}\text { SSC } \\
\left({ }^{\circ} \text { Brix }\right)^{\mathrm{y}}\end{array}$ & $\begin{array}{c}\text { TA } \\
(\mathrm{g} / 100 \mathrm{~g})^{\mathrm{y}}\end{array}$ \\
\hline 2012 & & & & & \\
UMH 916 & $5.19^{\mathrm{x}} \mathrm{a}$ & $135.3 \mathrm{c}$ & $35.4 \mathrm{a}$ & $5.24 \mathrm{a}$ & $0.81 \mathrm{a}$ \\
UMH 972 & $4.52 \mathrm{ab}$ & $189.2 \mathrm{a}$ & $22.1 \mathrm{~b}$ & $4.97 \mathrm{ab}$ & $0.76 \mathrm{ab}$ \\
UMH 1127 & $4.58 \mathrm{ab}$ & $164.9 \mathrm{~b}$ & $25.4 \mathrm{~b}$ & $4.46 \mathrm{~b}$ & $0.66 \mathrm{ab}$ \\
UMH 1139 & $4.76 \mathrm{ab}$ & $164.2 \mathrm{~b}$ & $27.0 \mathrm{~b}$ & $4.35 \mathrm{~b}$ & $0.82 \mathrm{a}$ \\
UMH 1200 & $4.16 \mathrm{~b}$ & $153.7 \mathrm{~b}$ & $25.1 \mathrm{~b}$ & $4.65 \mathrm{~b}$ & $0.61 \mathrm{~b}$ \\
Accession M18 & $4.45 \mathrm{ab}$ & $165.7 \mathrm{~b}$ & $28.2 \mathrm{~b}$ & $4.52 \mathrm{~b}$ & $0.61 \mathrm{~b}$ \\
2013 & & & & & \\
UMH 916 & $6.20 \mathrm{a}$ & $136.0 \mathrm{c}$ & $45.3 \mathrm{a}$ & $4.95 \mathrm{ab}$ & $0.42 \mathrm{abc}$ \\
UMH 972 & $5.25 \mathrm{ab}$ & $220.0 \mathrm{a}$ & $25.0 \mathrm{c}$ & $4.67 \mathrm{bc}$ & $0.40 \mathrm{abc}$ \\
UMH 1127 & $5.62 \mathrm{ab}$ & $157.7 \mathrm{bc}$ & $36.2 \mathrm{ab}$ & $4.42 \mathrm{~cd}$ & $0.45 \mathrm{ab}$ \\
UMH 1139 & $6.22 \mathrm{a}$ & $158.7 \mathrm{bc}$ & $38.1 \mathrm{ab}$ & $4.32 \mathrm{~cd}$ & $0.47 \mathrm{a}$ \\
UMH 1200 & $4.28 \mathrm{c}$ & $133.5 \mathrm{c}$ & $33.1 \mathrm{bc}$ & $4.32 \mathrm{~cd}$ & $0.34 \mathrm{c}$ \\
Accession M18 & $4.84 \mathrm{bc}$ & $185.1 \mathrm{~b}$ & $29.3 \mathrm{bc}$ & $4.14 \mathrm{~d}$ & $0.34 \mathrm{c}$ \\
2014 & & & & \\
UMH 916 & $5.82 \mathrm{a}$ & $118.4 \mathrm{c}$ & $50.4 \mathrm{a}$ & $4.94 \mathrm{~b}$ & $0.52 \mathrm{abc}$ \\
UMH 972 & $4.82 \mathrm{~b}$ & $206.8 \mathrm{a}$ & $24.0 \mathrm{~b}$ & $4.86 \mathrm{~b}$ & $0.54 \mathrm{ab}$ \\
UMH 1127 & $4.73 \mathrm{~b}$ & $164.8 \mathrm{~b}$ & $29.5 \mathrm{~b}$ & $4.67 \mathrm{bc}$ & $0.49 \mathrm{bc}$ \\
UMH 1139 & $4.81 \mathrm{~b}$ & $173.5 \mathrm{~b}$ & $29.8 \mathrm{~b}$ & $4.55 \mathrm{c}$ & $0.45 \mathrm{c}$ \\
UMH 1200 & $3.11 \mathrm{c}$ & $131.0 \mathrm{c}$ & $26.1 \mathrm{~b}$ & $5.41 \mathrm{a}$ & $0.52 \mathrm{abc}$ \\
Accession M18 & $4.61 \mathrm{~b}$ & $155.0 \mathrm{~b}$ & $30.4 \mathrm{~b}$ & $4.77 \mathrm{bc}$ & $0.57 \mathrm{a}$ \\
\hline
\end{tabular}

${ }^{\mathrm{z}}$ Mean of 6-8 plants per plot for two replicates.

y Mean of 10 fruits in the same stage of ripening (with $>50 \%$ of the surface showing red color) per plot for two replicates.

${ }^{\mathrm{x}}$ Mean values in a column followed by a different letter are significantly different according to NewmanKeuls's multiple range test $(P<0.05)$. 

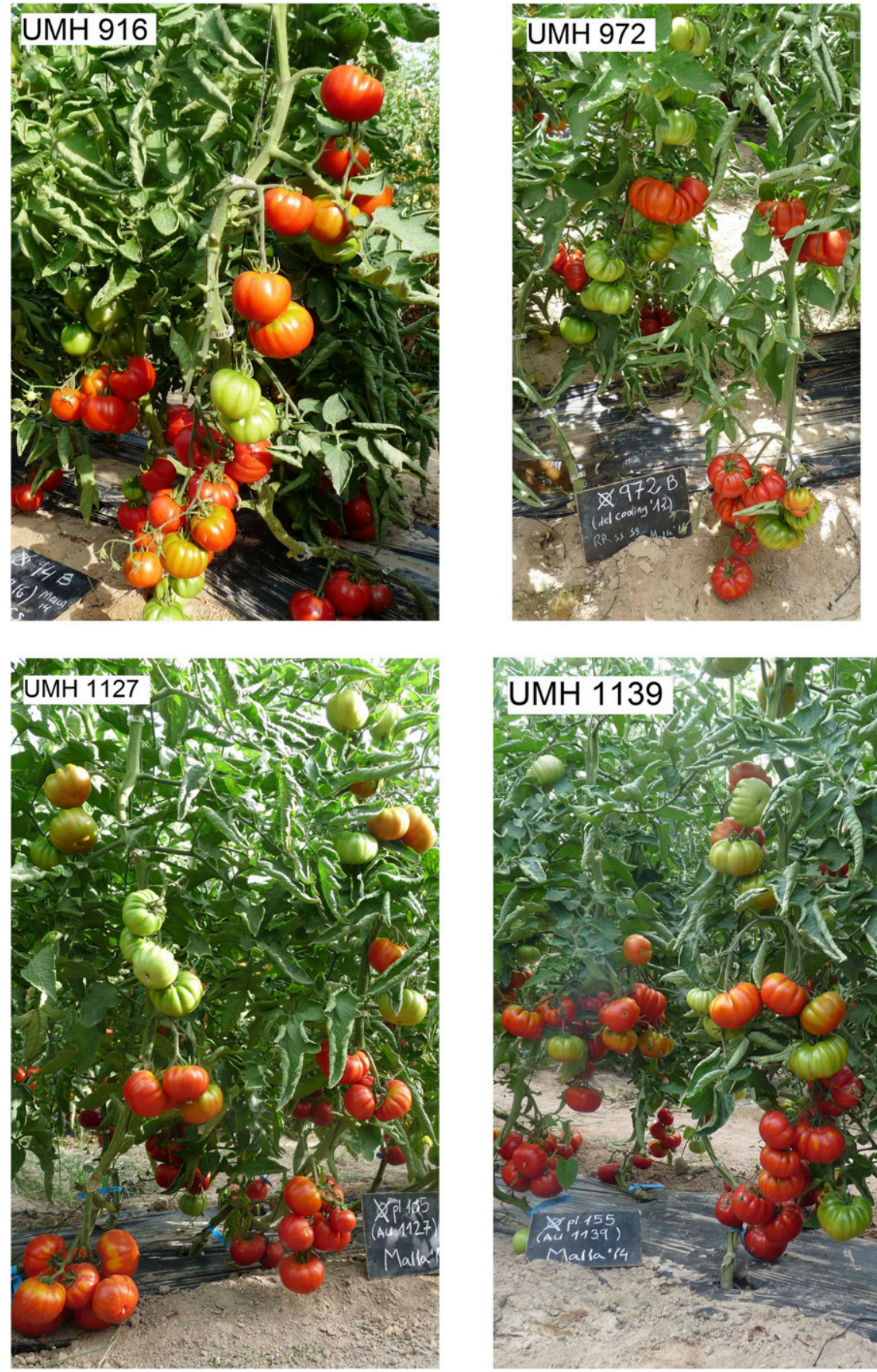

Fig. 1. Plants with fruits in different ripening states of the breeding lines UMH 916, UMH 972, UMH 1127, and UMH 1139.

plants) were transplanted, and crossed with the recurrent parent. Only the best plants (between two and four) were selected for further backcrossing. After the selfing of a $\mathrm{BC}_{10}$ single triple heterozygous plant, followed by two generations of selfing and selection, the pure-breeding UMH 916 and $\mathrm{UMH} 972$ lines, homozygous for $\mathrm{Tm}-2^{a}$ (Table 1), were selected using molecular markers and multiplied by self-pollination in a greenhouse, under controlled conditions. The pure-breeding UMH 1127 and UMH 1139 lines, homozygous for $T m-2^{a}$ and $S w-5$ (Table 1), were selected and multiplied in the same way, after the selfing of a $\mathrm{BC}_{6}$ single triple heterozygous plant.

\section{Description and Performance}

UMH 916 and UMH 972 are homozygous for $T m-2^{a}$ (ToMV resistance gene), whereas UMH 1127 and UMH 1139 are homozygous for $T m-2^{a}$ and $S w-5$ (ToMV and TSWV resistance genes, respectively). All the breeding lines have indeterminate growth with intermediate foliage density. Ripe fruits have red flesh, the green shoulders are less intense than those of the original landrace, and do not separate easily from pedicels during harvest. UMH 916 has slightly flattened and weakly ribbed fruits, with an average weight between 115 and $140 \mathrm{~g}$, and round-ellipsoidal cross-sectional shape (Fig. 1A). UMH 972 has very flattened and strongly ribbed fruits, with an average weight between 180 and $220 \mathrm{~g}$, and irregular cross-sectional shape (Fig. 1B). UMH 1127 and UMH 1139 have intermediately flattened and moderately ribbed fruits, with an average weight between 150 and $180 \mathrm{~g}$, and ellipsoidal-irregular cross-sectional shape (Fig. 1C and D, respectively).

From 2012 to 2014, the four breeding lines, the breeding line UMH 1200 (homozygous for $T m-2^{a}, S w-5$, and $\left.T y-1\right)$ and the cultivar M18 were cultivated in a meshcovered net house in the spring-summer production cycle, the most important cycle in the traditional area of cultivation for Muchamiel tomato. For the agronomic traits, the four breeding lines showed similar or better marketable yield than the cultivar M18 and the breeding line UMH 1200 (Table 2). The yield advantages of the four new breeding lines, as compared with UMH 1200 , were most obvious in 2014. These suggest the idea that the introgression of the $T y-1$ gene, that confers resistance to TYLCV, has the higher negative effect in yield, as previously has been reported in several Spanish landrace breeding lines (Rubio et al., 2012; García-Martínez et al., 2014). In the three studied cycles, the UMH 916 breeding line is the one that had a higher marketable yield (Table 2), ranging between 5.19 and $6.20 \mathrm{~kg} /$ plant, which are more than acceptable values for landrace breeding lines. Regarding the average fruit weight, UMH 1127 and UMH 1139 breeding lines are similar to the accession M18 values. However, the UMH 972 breeding line has average fruit weight greater than M18 accession, while the UMH 916 breeding line has lower (Table 2). There are no important differences between breeding lines and M18 accession for soluble solids content and titratable acidity (Table 2). In preliminary sensory analysis, organoleptic values of four breeding lines were similar to the M18 accession (data not shown).

\section{Use}

UMH 916 and UMH 972 have genetic resistance to ToMV, whereas UMH 1127 and UMH 1139 have genetic resistance to ToMV and TSWV, viruses that cause variable but intense damages in southeastern Spain tomato landrace crops, especially in open field conditions. These four breeding lines are available for cropping in the spring-summer production cycle, the most important cycle in the traditional area of cultivation for Muchamiel tomato, when the TYLCV incidence is less intense, due to the low population levels of the whitefly vector Bemisia tabaci (Genn.). These breeding lines allow farmers to obtain a harvest similar or better than the cultivar M18 and UMH 1200 breeding line (genetic resistant to ToMV, TSWV, and TYLCV), in a mesh-covered net house in the spring-summer crop cycle. As with previous releases produced by this breeding program, UMH 916, UMH 972, UMH 1127, and UMH 1139 are under study 
to be marketed by private companies. These breeding lines may be used to develop $F_{1}$ hybrids by crossing them with other Muchamiel landraces to increase yield by using the genetic resistance in a heterozygous state, as well as to be used in breeding programs to facilitate the introgression of the resistance genes into other landraces.

\section{Availability}

Small trial seed samples of all the breeding lines are available for research purposes (please contact authors).

\section{Literature Cited}

García-Martínez, S., A. Grau, A. Alonso, F. Rubio, M. Valero, and J.J. Ruiz. 2011. UMH 1200, a breeding line within the Muchamiel tomato type, resistant to three viruses. HortScience 46:1054-1055.

García-Martínez, S., A. Grau, A. Alonso, F. Rubio, M. Valero, and J.J. Ruiz. 2014. UMH 1422 and UMH 1415, two fresh-market tomato breeding lines resistant to Tomato mosaic virus and Tomato spotted wilt virus. HortScience 49:1465-1466.

Pérez de Castro, A., J.M. Blanca, M.J. Díez, and F. Nuez. 2007. Identification of a CAPS marker tightly linked to the Tomato yellow leaf curl disease resistance gene Ty-1 in tomato. Eur. J. Plant Pathol. 117:347-356.
Picó, B., J. Herraiz, J.J. Ruiz, and F. Nuez. 2002. Widening the genetic basis of virus resistance in tomato. Sci. Hort. 94(1-2):73-89.

Rubio, F., S. García-Martínez, A. Alonso, A. Grau, M. Valero, and J.J. Ruiz. 2012. Introgressing resistance genes into traditional tomato varieties: Effects on yield and quality. Acta Hort. 935:29-33.

Tanksley, S.D., D. Bernachi, T. BeckBunn, D Emmatty, Y. Eshed, S. Inai, J. Lopez, V. Petiard, H. Sayama, J. Uhlig, and D. Zamir. 1998. Yield and quality evaluations on a pair of processing tomato lines nearly isogenic for the $T m 2^{a}$ gene for resistance to the Tobacco mosaic virus. Euphytica 99:77-83. 